\title{
Trace Elements in Scalp-Hair of Students from Four Different Environmental Contexts
}

\author{
Mohamed E. M. Eisa ${ }^{1,2 *}$, Johan André Mars ${ }^{3,4}$ \\ ${ }^{1}$ Northern Border University, Department of Physics, P.O. Box 1631, Arar, Kingdom of Saudi Arabia \\ ${ }^{2}$ Sudan University of Science \& Technology, Department of Physics, P.O. Box 407, Khartoum, 11113, Sudan \\ ${ }^{3}$ Department of Medical Biosciences, University of the Western Cape, Private Bag X17, \\ Bellville, 7535, Rep. of South Africa \\ ${ }^{4}$ Faculty of Health and Wellness Sciences, Cape Peninsula University of Technology, PO Box 1906, \\ Bellville, 7535, Rep. of South Africa
}

Received: 29 December 2019

Accepted: 9 April 2020

\begin{abstract}
Many individuals come into contact, at times unawares, with substances that due to concentrations can be classified as environmental pollutants. These substances can have marked adverse health effects on the individual when present in toxic concentration ranges. Excess accumulation of these elements can be determined in hair since hair does not have an excretion point. To investigate any such occurrences, scalp-hair samples were collected from male and female student volunteers $(n=183)$, aged between 20 and 23 years. These students were attending the Sudan University of Technology, but originated from four regions in Sudan. Elemental concentrations were quantitatively determined by X-ray emission. The study shows that the different inter-region and inter-gender results revealed alarming health effects of environmental pollution.
\end{abstract}

Keywords: mining, agriculture, effluent, environmental pollution, scalp-hair, X-ray emission

\section{Introduction}

Global industrialization has been spurred on the rapid development of economic activities such as mining and agriculture [1, 2]. Despite this global initiative, there are still impoverished communities that face hazardous circumstances daily when plying their trade. Scalp hair specimens become the most preferable specimen for non-invasive sampling [3, 4]. This is due to the ease of sampling that can be effected at low cost,

*e-mail: memeisa@yahoo.com which facilitates the storage and transport processes that offer several advantages for analysis including matrix stability in the human body.

An investigation of $\mathrm{Pb}$ poisoning was conducted [5] of individuals who were employed in an acid lead battery plant. To obtain a detailed concentration, the hair of only employees working for at least six consecutive months were analysed. In that instance, the workers were occupationally exposed to $\mathrm{Pb}$ fumes and dust from various activities. The hair analyses indicated significantly higher levels of $\mathrm{Pb}, \mathrm{Sb}, \mathrm{As}$, and $\mathrm{Cd}$. More so, a linear concentration dependence existed of $\mathrm{Cr}$ with $\mathrm{Pb}, \mathrm{Ni}$ and $\mathrm{Sb}$. For $\mathrm{Mn}$ concentration, there were linear correlations with the concentrations of $\mathrm{Ni}$ 
and $\mathrm{Sb}$. The Ni concentration on the other hand, correlated positively with those of $\mathrm{Mn}$ and $\mathrm{Cr}$, and negatively with the concentration of Cd. Similarly, the concentration of As correlated linearly with those of $\mathrm{Sn}, \mathrm{Sb}$ and $\mathrm{Hg}$, the concentration of $\mathrm{Se}$ correlated linearly positive wth that of $\mathrm{Ni}$; the $\mathrm{Sn}$ concentration with that of As, the $\mathrm{Sb}$ concentration with those of As, $\mathrm{Mn}, \mathrm{Sn}$ and $\mathrm{Se}$, and negatively with those of $\mathrm{Ni}$ and $\mathrm{Hg}$. These metals are present in $\mathrm{Pb}$ ores and as such pose an additional toxicity threat to the individuals present in the occupational environment. Various other investigations have also been performed to assess the concentrations of other elements such as As and Mn [6-8]. It was found that these and other toxic elements can cause irreversible damage to the organs of the body.

The presence and effects of toxic elements are not limited to industrial activities. Fish samples from the northern part of the Persian Gulf [9]. Fish from five different species: grunt, flathead, greasy grouper, tigertooth croaker, and silver pomfret were analysed. It was found that these fish contained excessive amounts of $\mathrm{Hg}$. Hence the contaminations was not limited to one species; and hence a large marine volume have been polluted. In addition, $\mathrm{Hg}$ and the compound methylmercury were analyzed in scalp hair of 19 fishermen. These men were living in the same coastal regions for several weeks and hence have been consuming fish from the marine area. Of concern was the $\mathrm{Hg}$ concentrations, which were higher than $0.5 \mu \mathrm{g} \cdot \mathrm{g}^{-1}$. That concentration was also higher than the prescribed maximum concentration of the World Health Organization (WHO). A plethora of other investigations have been completed, of which [10, 11] are just a few examples. These investigations and subsequent findings however sketch a grim image of the extent of contamination of not only the natural environment but, important, also the health conditions of individuals present in these occupational environments. However, more importantly is the knowledge that those individuals were not aware of their physical contamination.

Sudan has also experienced an industrial revolution [12-15]. As would be expected, the contamination of individuals due to local pollution has also occurred. In the urban areas of Sudan are various micro industries. To investigate whether any contamination have happened, samples of the scalp-hairs were collected from different ages of worker of Sudanese origin, that were employed in an iron welding workshop and also in a perfume factory in Omdurman city [16]. The samples collected from different ages and genders in both these two sites. The resultant hair analyses of the two major groups of workers indicated that the concentrations of $\mathrm{Ca}, \mathrm{Fe}$ and $\mathrm{Sr}$ in the workshop group and $\mathrm{Mn}, \mathrm{Cu}, \mathrm{Zn}$, $\mathrm{Pb}$ and $\mathrm{Hg}$ in the perfume factory were significantly higher than those concentrations of the International Atomic Energy Agency (IAEA) data and of other countries [17]. It should be noted that those workers were not aware of the hazards that they faced in their occupational environment. More so, they were not informed of these hazards. With industrial development in Sudan [18], such instances are a great cause for concern. In addition, Sudan only has a per capita income of US \$2898.15 per year; [19] which translates to approximately US\$ of 240 per month. This fact in turn places a burden on the university students when study, as an income of that nature do not ensure a successful study period. Thus students would be compelled to seek university vacation employment. Since the country economy is growing they would seek employment with companies such as mining.

It is of great importance whether these students would be alerted to the occupational hazards present in the work environment. It is therefore important that the areas of industrial development be considered so as to delineate the work environments to which the students might be exposed.Mineral resources present in Sudan are petroleum, natural gas, gold, silver, gold, silver, chrome, asbestos, manganese, gypsum, mica, zinc, iron, lead, uranium, copper, kaolin, cobalt, granite, nickel, tin and more [12-14, 20-22].

Gold ores occurs in nearly the entire Red Sea state, the central and northern parts of the River Nile state and the north-eastern part of the Northern state [12-44]. Ores are also present the states of Kassala, Gedaref, Northern and Southern Kordofan states and the southern part of the Southern Darfur state. Hence, gold occurs over approximately $40 \%$ of the surface area of Sudan. Mining of such large area has to be effected in the least costly manner. Cyanidation has been perfected over a long period of time and is therefore the least costly process [20]. Even though the resultant concentration of cyanide is less than $10 \mathrm{ppm}$, this concentration is still toxic to the environment.

Other process methodologies exist; these methodologies are extremely costly and considering the vast tonnage of gold that can still be mined would render the mining not feasible. Studies of heavy metal pollution in mining areas have mainly focused on the mined elements; the associated heavy metals, which are important environmental pollutants that lower the mining grade, have mostly been ignored. [12-14].

Among these problems, heavy metal pollution has attracted more attention because of their toxicity for human health, and their mobility from the polluted soil/ water/air to living beings.

The diseases with which the concentration imbalances of these elements have been associated are liver disease [22, 23] changes in micronutrient concentrations following anti-inflammatory treatment in patients with gastrointestinal cancer risk [23], uræmic toxicity [24], cardiovascular diseases [24] and also various other elements [24-26]. More so, a database of the concentration of elements in the human body was established by Versieck [25]. In addition to their own environmental pollution, the interactions among heavy metals and pesticides may also produce synergistic or antagonistic effects to form compound pollution. 
The limit of detection of the converted toxic concentrations also determine the type of instrumental technique of analysis that should be used. The concentrations of Frieden (quantity-, essential-, promotive- and toxic-) elements [26] present in the human body, have been analyzed mostly after invasive clinical sampling of blood and preparation of the serum and plasma [27] in the blood, and at times whole blood, analysis [28]. Of late, there has been a trend towards non-invasive analysis. The use of fingernails [29] and hair [30] have shown promising results.

The hair ethnicity was classified as European, Asian and African [31, 32]. Since the different types of hair have significantly different concentrations, it is expected that other elements would also differ in concentrations. Hence, different normal concentration values (norms) for evaluating toxic concentrations are needed. Norms of elemental concentrations have already been established [33, 34]. Ethnicity in Sudan is widely spread and hence no clear limitation on hair composition could be achieved. The lower and upper limits from these studies were used to delineate toxic limits $[35,36]$.

The advantage of hair specimens is the simplicity of sampling and ease of handling and storing of the samples for extended periods. Since the elemental content of hair is high relative to other biological tissues and fluids, it can advantageously be analyzed and for this reason hair element analysis has attracted the interest of many disciplines including environmental, forensic and medical sciences [32, 37, 38]. As element levels in human hair may reflect the course of the corresponding blood plasma concentrations, hair analysis is of increasing interest both in nutrition research and in toxicology [39]. Thus, hair elemental concentration can be used to retrace the history of exposure to a pollutant or the evolution of a biomarker for an extended time period. In order to achieve such a past history tracing. Some of these elements are of endogenous origin, others of exogenous origin, reflecting the high propensity of hair for absorbing chemical elements. Because of its growth process, hair might in addition reveal the biomedical and environment history of the patient $[39,40]$. Human hair consists mainly of $\alpha$-keratin [34]. It is thus of consequence that the concentrations of elements in hair be determined with the utmost accuracy.

Ion beam analysis techniques, especially X-ray emission induced by proton bombardment, PIXE [41] have increasingly been used in the biological and medical fields for elemental composition analysis of tissue [29, 42]. The principal application is the determination of the concentrations of trace and minor elements, and in some cases also major elements, in the matrices of various types of samples [29, 43]. Backscattering spectrometry (BS) [43] is performed simultaneously with X-ray emission.
Table 1. Regions, principal towns or cites of origin, the gender and number of students who participated in the study.

\begin{tabular}{|c|c|c|c|c|}
\hline Region & Place & Gender & $\mathrm{n}$ & \\
\hline Central & Bahri & Female & 9 & \\
\hline Central & Khartoum & Female & 10 & \\
\hline Central & Omdurman & Female & 7 & \\
\hline Central & Bahri & Male & 7 & \\
\hline Central & Khartoum & Male & 9 & \\
\hline Central & Omdurman & Male & 8 & 50 \\
\hline Eastern & Gedaref & Female & 8 & \\
\hline Eastern & Halfa & Female & 5 & \\
\hline Eastern & Kassala & Female & 10 & \\
\hline Eastern & Gedaref & Male & 9 & \\
\hline Eastern & Halfa & Male & 9 & \\
\hline Eastern & Kassala & Male & 5 & 46 \\
\hline Northern & Atbara & Female & 11 & \\
\hline Northern & Dongala & Female & 4 & \\
\hline Northern & Marawe & Female & 7 & \\
\hline Northern & Atbara & Male & 6 & \\
\hline Northern & Dongala & Male & 7 & \\
\hline Northern & Marawe & Male & 8 & 43 \\
\hline Western & Al Fashir & Female & 9 & \\
\hline Western & Al Obied & Female & 4 & \\
\hline Western & Nyala & Female & 6 & \\
\hline Western & Al Fashir & Male & 7 & \\
\hline Western & Al Obied & Male & 12 & \\
\hline Western & Nyala & Male & 6 & 44 \\
\hline & & & & \\
\hline
\end{tabular}

\section{Experimental}

\section{Sample Preparation}

Hair samples were collected from $n=183$ healthy appearing male and female volunteering students, attending the Sudan University of Science and Technology in Khartoum, Sudan. Their ages ranged from 20 to 23 years. Though the students had been living in the urban areas of Khartoum for the past 5 years, they spent university recess periods in their respective regions of permanent residence. The principal towns or cites of origin in Table 1 can be correlated with the map of Sudan, shown in Fig. 1.

The samples were washed with copious amounts of distilled water, rinsed with ethanol, and allowed to dry to room temperature in a dust-free environment. Samples were then embedded in resin. Cross sections 

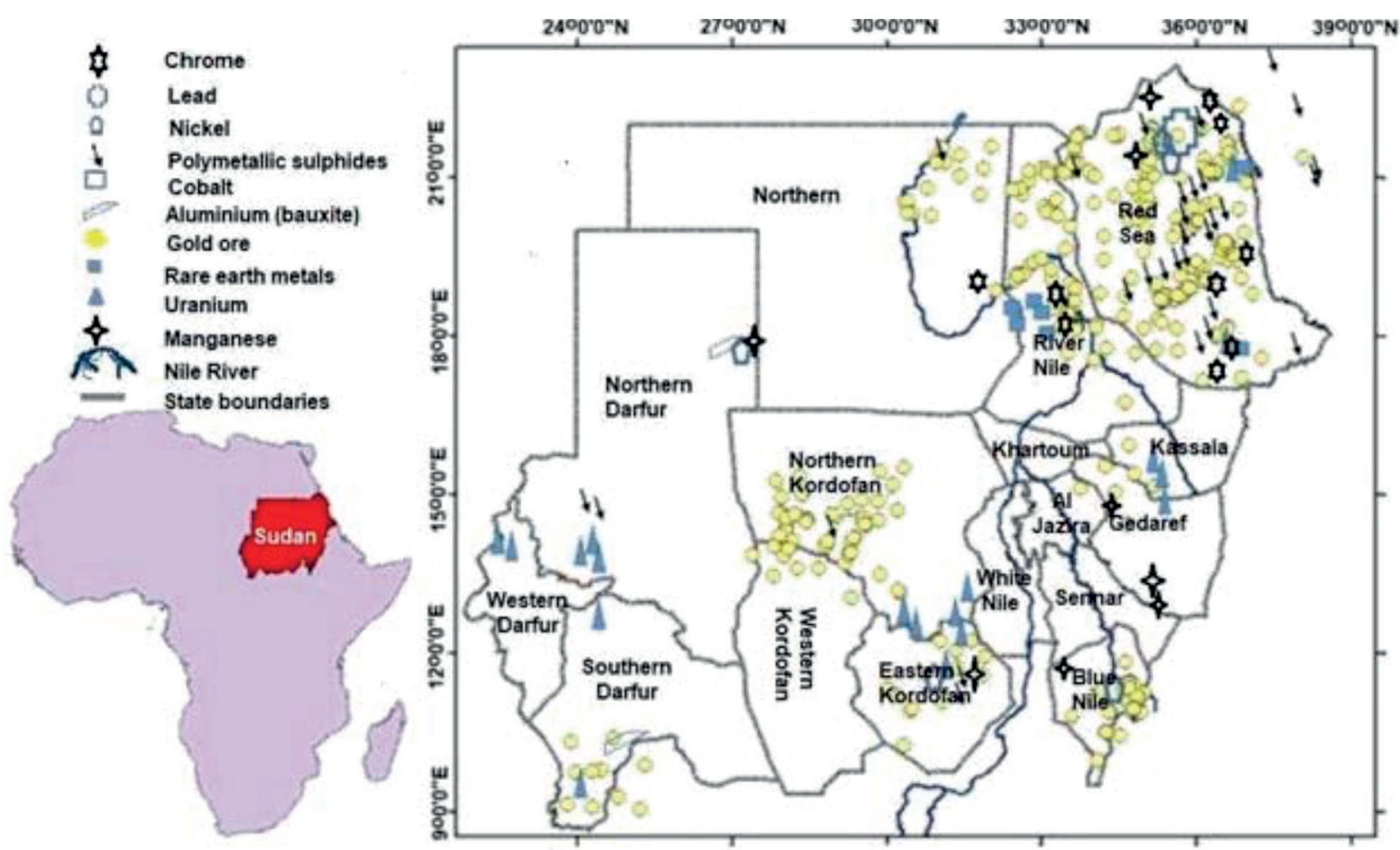

Fig. 1. Map of Sudan, indicating the mining locations and types of mining. Data were obtained from $[4,6]$. Map outline obtained with courtesy from googlemaps (freely available).

of thicknesses varying from 5 to $6 \mu \mathrm{m}$, were cut with a microtome (UNILAB-102FAM, Haryana, India). The sections were coated in a Quorum coater (Quorum Technologies Ltd, London, UK) with an approximately 10 nanometers thick layer of carbon. The coating prevents charging during irradiation of the sections with a beam of protons. The increase in the yield of the characteristic X-rays from an element in a hair with the energy of the incident proton beam depends significantly on the distribution of the element over the transverse cross section of the hair.

\section{Instrumentation}

The samples were irradiated at the $6 \mathrm{MeV}$ Van de Graff Accelerator Nuclear Microprobe (NMP) facility

Table 2. Evaluation of the certified standard IAEA and NIST 1515 used in this study.It should be noted that data supplied were only the element analysed and the concentration average, the standard deviation and the ranges of the concentrations.

\begin{tabular}{|c|c|c|c|c|c|c|c|c|c|c|}
\hline & \multicolumn{9}{|c|}{ NIST1515 } & \multicolumn{5}{c|}{ IAEA 085 } \\
\hline $\mathrm{Sym}$ & $\mathrm{c}_{\mathrm{i}}$ & $\boldsymbol{\sigma}_{\mathrm{ci}}$ & $\mathrm{R}$ & $\mathrm{x}_{\mathrm{i}}$ & $\% \varepsilon$ & $\mathrm{c}_{\mathrm{i}}$ & $\boldsymbol{\sigma}_{\mathrm{ci}}$ & $\mathrm{R}$ & $\mathrm{x}_{\mathrm{i}}$ & $\% \varepsilon$ \\
\hline $\mathrm{Ca}$ & 15250 & 1000 & $\mathrm{NA}$ & 15312 & -0.41 & 929 & & $847-1010$ & 922 & 0.3 \\
\hline $\mathrm{Cl}$ & 582 & 15 & $\mathrm{NA}$ & 594 & 2.06 & & & & & \\
\hline $\mathrm{Cu}$ & 5.69 & 0.13 & $\mathrm{NA}$ & 5.71 & 3.51 & 16.8 & & $15.7-17.8$ & 17.3 & 0.3 \\
\hline $\mathrm{Fe}$ & 82.7 & 2.6 & $\mathrm{NA}$ & 81.4 & 1.33 & 79.3 & & $71.0-87.8$ & 78.4 & 0.9 \\
\hline $\mathrm{Mn}$ & 54.1 & 1.1 & $\mathrm{NA}$ & 55.3 & 2.40 & 8.8 & & $8.4-9.2$ & 9.2 & 2.27 \\
\hline $\mathrm{Ni}$ & 0.936 & 0.094 & $\mathrm{NA}$ & 0.9 & 3.22 & & & & & \\
\hline $\mathrm{P}$ & 1593 & 68 & $\mathrm{NA}$ & 1614 & 1.06 & & & & & \\
\hline $\mathrm{K}$ & 16080 & 210 & $\mathrm{NA}$ & 15897 & 0.52 & & & & & \\
\hline $\mathrm{V}$ & 0.25 & 0.027 & $\mathrm{NA}$ & 0.3 & 16.0 & & & & \\
\hline $\mathrm{Zn}$ & 12.45 & 0.43 & $\mathrm{NA}$ & 12.18 & 2.17 & 163 & & & \\
\hline $\mathrm{Se}$ & $\mathrm{NA}$ & $\mathrm{NA}$ & $\mathrm{NA}$ & $\mathrm{NA}$ & $\mathrm{NA}$ & 1.07 & & $0.96-1.17$ & 1.1 & 0.8 \\
\hline
\end{tabular}


Table 3. Average concentrations and standard deviations of the quantity elements in the hair specimens per gender per place. The concentration of S is given in percentage, and those of the other elements are given in ppm. ND indicates that the concentration of the element is below the minimum detection limits (MDLs) and therefore not determinable. The MDLs, and therefore not determinable. The MDLs, and the normal values (Norms) are shown.

\begin{tabular}{|c|c|c|c|c|c|c|}
\hline Place & Gender & $\mathrm{P}$ & S & $\mathrm{Cl}$ & K & $\mathrm{Ca}$ \\
\hline Bahri & Female & ND & $4.11 \pm 0.25$ & $915 \pm 55$ & $364 \pm 31$ & $484 \pm 38$ \\
\hline Khartoum & Female & ND & $4.18 \pm 0.25$ & $339 \pm 43$ & $165 \pm 20$ & $198 \pm 15$ \\
\hline Omdurman & Female & $140 \pm 18$ & $4.59 \pm 0.14$ & $12 \pm 5$ & $145 \pm 31$ & $422 \pm 55$ \\
\hline Bahri & Male & $3.9 \pm 0.8$ & $3.91 \pm 0.16$ & $92 \pm 9$ & $167 \pm 18$ & $108 \pm 47$ \\
\hline Khartoum & Male & ND & $5.13 \pm 0.36$ & $1376 \pm 62$ & $344 \pm 15$ & $592 \pm 77$ \\
\hline Omdurman & Male & ND & $4.36 \pm 0.44$ & ND & $119 \pm 26$ & $378 \pm 39$ \\
\hline Gedaref & Female & $1389 \pm 44$ & $4.90 \pm 0.10$ & $128 \pm 29$ & $647 \pm 59$ & $1054 \pm 44$ \\
\hline Halfa & Female & $903 \pm 41$ & $4.69 \pm 0.19$ & $164 \pm 43$ & $1347 \pm 47$ & $914 \pm 64$ \\
\hline Kassala & Female & $1241 \pm 44$ & $4.88 \pm 0.34$ & $845 \pm 33$ & $2401 \pm 37$ & $833 \pm 46$ \\
\hline Gedaref & Male & $886 \pm 58$ & $4.65 \pm 0.42$ & $1769 \pm 70$ & $1047 \pm 63$ & $645 \pm 35$ \\
\hline Halfa & Male & $1021 \pm 89$ & $4.85 \pm 0.39$ & $1223 \pm 58$ & $2788 \pm 82$ & $1346 \pm 22$ \\
\hline Kassala & Male & $2185 \pm 152$ & $5.04 \pm 0.05$ & $280 \pm 18$ & $1945 \pm 15$ & $1073 \pm 30$ \\
\hline Atbara & Female & $2103 \pm 154$ & $4.95 \pm 0.20$ & $812 \pm 74$ & ND & $598 \pm 27$ \\
\hline Dongala & Female & $1123 \pm 79$ & $4.79 \pm 0.43$ & $762 \pm 55$ & $455 \pm 36$ & $646 \pm 52$ \\
\hline Marawe & Female & ND & $4.86 \pm 0.10$ & $877 \pm 36$ & $528 \pm 41$ & $712 \pm 66$ \\
\hline Atbara & Male & $752 \pm 45$ & $4.79 \pm 0.19$ & $1894 \pm 72$ & $1703 \pm 47$ & $645 \pm 44$ \\
\hline Dongala & Male & $1848 \pm 89$ & $4.94 \pm 0.25$ & $280 \pm 34$ & $1679 \pm 35$ & $1184 \pm 67$ \\
\hline Marawe & Male & $936 \pm 38$ & $4.84 \pm 0.34$ & $1223 \pm 150$ & $2113 \pm 51$ & $1247 \pm 73$ \\
\hline Al Fashir & Female & ND & $4.39 \pm 0.13$ & $786 \pm 40$ & $209 \pm 17$ & $801 \pm 33$ \\
\hline Al Obied & Female & ND & $4.30 \pm 0.26$ & $900 \pm 32$ & $221 \pm 26$ & $768 \pm 26$ \\
\hline Nyala & Female & ND & $4.19 \pm 0.25$ & $708 \pm 46$ & $382 \pm 13$ & $568 \pm 38$ \\
\hline Al Fashir & Male & $5.2 \pm 0.4$ & $4.67 \pm 0.09$ & $135 \pm 17$ & $168 \pm 28$ & $691 \pm 37$ \\
\hline Al Obied & Male & ND & $4.43 \pm 0.13$ & $612 \pm 20$ & $335 \pm 47$ & $541 \pm 40$ \\
\hline \multirow[t]{3}{*}{ Nyala } & Male & ND & $4.02 \pm 0.36$ & ND & $230 \pm 60$ & $411 \pm 18$ \\
\hline & Norms & $132-300$ & $4.53-5.10$ & $50-250$ & 9-77 & $192-665$ \\
\hline & MDLs & 2.0 & 1.6 & 2.8 & 1.8 & 4.5 \\
\hline
\end{tabular}

[45] at iThemba LABS, Somerset West, Rep. of South Africa, analysis were selected at particular microregions of hair-shaft cross sections using. Beam energy was varied from 1.50 to $3.00 \mathrm{MeV}$ and the current was maintained at approximately 200 pico-amperes. The beam spot size was $2 \times 3 \mu \mathrm{m}^{2}$ and the dwell time of the beam per spot size area was 10 milliseconds. The emitted X-rays were detected with a PGT detector (Princeton Gamma Tech, Princeton, USA) of $100 \mathrm{~mm}^{2}$ surface area and a resolution of $125 \mathrm{eV}$ at $\mathrm{Mn} \mathrm{K}_{\alpha} \mathrm{X}$-ray line. The detector was mounted at $135^{\circ}$ to the incoming beam. Back-scattered particles were measured with a silicon surface barrier detector (Ortec, Houston, USA), mounted at $176^{\circ}$ to the incoming beam. Pile-up rejection was controlled by a beam-on-demand system.
Organic tissue consists mostly of the major elements $\mathrm{C}, \mathrm{H}^{4}, \mathrm{O}$ and $\mathrm{N}$ and $\mathrm{S}$, to a smaller percentage mass per mass [46]. Small changes in the Frieden elements [26] compositions would there not affect the concentration of the major elements significantly [46] and therefore the concentrations of these elements were not determined. The concentrations of the elements $\mathrm{S}, \mathrm{Cl}, \mathrm{K}, \mathrm{Ca}, \mathrm{Sc}$, $\mathrm{Ti}, \mathrm{V}, \mathrm{Cr}, \mathrm{Mn}, \mathrm{Fe}, \mathrm{Co}, \mathrm{Cu}, \mathrm{Zn}, \mathrm{As}, \mathrm{Se}, \mathrm{Br}$ and $\mathrm{Sr}$ were however determined.

\section{Quantification Qualification of Data}

The PIXE data obtained were quantified using the Geo-PIXE II software program with dynamic analysis [47]. The back-scattered data were quantified with 
Table 4. The average concentrations and standard deviations, in ppm, of the essential elements in the hair specimens. per gender per place. ND indicates that the concentration of the element is below the minimum detection limits (MDLs). The MDLs, and the normal values (Norms) are shown. Concentrations less than $10 \mathrm{ppm}$ is expressed to the first decimal, and those of $10 \mathrm{ppm}$ or higher concentration to whole numbers.

\begin{tabular}{|c|c|c|c|c|c|c|c|c|}
\hline Place & Gender & $\mathrm{Cu}$ & $\mathrm{Fe}$ & $\mathrm{Mn}$ & $\mathrm{Zn}$ & Co & $\mathrm{Cr}$ & $\mathrm{Se}$ \\
\hline Bahri & Female & $5.8 \pm 1.6$ & $74 \pm 5$ & $1.8 \pm 0.2$ & $183 \pm 5$ & $1.5 \pm 0.3$ & $5.6 \pm 0.6$ & $12 \pm 3$ \\
\hline Khartoum & Female & $8.3 \pm 1.1$ & $66 \pm 7$ & $2.8 \pm 1.2$ & $124 \pm 18$ & $39 \pm 9$ & $3.6 \pm 0.4$ & $1.5 \pm 0.2$ \\
\hline Omdurman & Female & $9.7 \pm 1.1$ & $75 \pm 7$ & $0.8 \pm 0.2$ & $28 \pm 3$ & $0.8 \pm 0.2$ & $0.5 \pm 0.2$ & $0.8 \pm 0.1$ \\
\hline Bahri & Male & $3.5 \pm 0.8$ & ND & $1.7 \pm 0.9$ & $191 \pm 12$ & $43 \pm 9$ & ND & $12 \pm 2$ \\
\hline Khartoum & Male & $6.8 \pm 1.4$ & $14 \pm 2$ & $8.0 \pm 1.7$ & $31 \pm 5$ & $21 \pm 2$ & $5.0 \pm 0.1$ & $8.5 \pm 0.3$ \\
\hline Omdurman & Male & $12 \pm 2$ & $66 \pm 5$ & $6.8 \pm 1.4$ & $214 \pm 32$ & $39 \pm 6$ & $4.6 \pm 0.1$ & $9.0 \pm 0.2$ \\
\hline Gedaref & Female & $14 \pm 4$ & $32 \pm 2$ & ND & $12 \pm 3$ & $43 \pm 3$ & $2.2 \pm 0.5$ & $1.3 \pm 0.2$ \\
\hline Halfa & Female & $7.2 \pm 1.2$ & $14 \pm 2$ & ND & $116 \pm 4$ & $33 \pm 3$ & $2.9 \pm 0.3$ & $2.8 \pm 0.3$ \\
\hline Kassala & Female & $4.0 \pm 0.4$ & $7.7 \pm 1.1$ & ND & $0.4 \pm 0.1$ & $44 \pm 4$ & $1.1 \pm 0.2$ & $6.0 \pm 0.1$ \\
\hline Gedaref & Male & $11 \pm 3$ & $48 \pm 4$ & $2.8 \pm 1.8$ & $15 \pm 2$ & $3.8 \pm 0.2$ & $3.6 \pm 0.1$ & $2.9 \pm 0.2$ \\
\hline Halfa & Male & $13 \pm 3$ & $94 \pm 5$ & $3.3 \pm 2.4$ & $17 \pm 3$ & $0.9 \pm 0.3$ & ND & $2.9 \pm 0.1$ \\
\hline Kassala & Male & $16 \pm 4$ & $120 \pm 10$ & ND & $114 \pm 8$ & $19 \pm 5$ & $2.8 \pm 0.2$ & $2.9 \pm 0.3$ \\
\hline Atbara & Female & $9.2 \pm 2.3$ & $65 \pm 5$ & ND & $130 \pm 35$ & $55 \pm 4$ & $19 \pm 4$ & $2.3 \pm 0.1$ \\
\hline Dongala & Female & $10 \pm 3$ & $74 \pm 6$ & ND & $262 \pm 58$ & $61 \pm 7$ & $26 \pm 3$ & $2.3 \pm 0.2$ \\
\hline Marawe & Female & $22 \pm 3$ & $101 \pm 7$ & ND & $108 \pm 14$ & $43 \pm 4$ & $13 \pm 3$ & $2.3 \pm 0.3$ \\
\hline Atbara & Male & $11 \pm 2$ & $56 \pm 2$ & ND & $25 \pm 2$ & $263 \pm 16$ & $12 \pm 2$ & $2.9 \pm 0.1$ \\
\hline Dongala & Male & $19 \pm 4$ & $10 \pm 2$ & $1.3 \pm 0.4$ & $37 \pm 6$ & $41 \pm 5$ & $5.5 \pm 0.5$ & $3.0 \pm 0.3$ \\
\hline Marawe & Male & $17 \pm 2$ & $37 \pm 3$ & ND & $234 \pm 26$ & $112 \pm 9$ & $10 \pm 2$ & $2.3 \pm 0.2$ \\
\hline Al Fashir & Female & $9.8 \pm 1.8$ & $14 \pm 2$ & $1.1 \pm 0.5$ & $30 \pm 6$ & $83 \pm 4$ & $4.9 \pm 0.1$ & ND \\
\hline Al Obied & Female & $12 \pm 3$ & $21 \pm 3$ & $1.4 \pm 0.6$ & $29 \pm 4$ & $39 \pm 4$ & $2.3 \pm 0.2$ & $1.9 \pm 0.3$ \\
\hline Nyala & Female & $19 \pm 4$ & $9.4 \pm 2.1$ & ND & $221 \pm 23$ & $46 \pm 3$ & $3.6 \pm 0.2$ & ND \\
\hline Al Fashir & Male & $5.1 \pm 1.5$ & $24 \pm 3$ & $2.8 \pm 0.3$ & $28 \pm 7$ & $38 \pm 4$ & $4.3 \pm 0.1$ & $2.5 \pm 0.2$ \\
\hline Al Obied & Male & $8.0 \pm 2.3$ & $19 \pm 2$ & $1.9 \pm 0.2$ & $58 \pm 7$ & $62 \pm 5$ & $4.7 \pm 0.1$ & $1.7 \pm 0.2$ \\
\hline \multirow[t]{3}{*}{ Nyala } & Male & $8.7 \pm 0.9$ & $14 \pm 2$ & $1.1 \pm 0.5$ & $107 \pm 12$ & $43 \pm 3$ & $3.3 \pm 0.3$ & $5.0 \pm 0.2$ \\
\hline & Norms & $8-27$ & $9-75$ & $0.3-0.9$ & $6-21$ & $0.3-1.3$ & $0.2-0.6$ & $0.1-1.9$ \\
\hline & MDLs & 1.4 & 0.2 & 0.2 & 0.9 & 0.2 & 1.8 & 1.3 \\
\hline
\end{tabular}

the RUMP [44] and the SimNRA [48] software programs.

The $\mathrm{R}$ statistical software [49] was used in the statistical evaluation of the data. A probability value of $p \leq 005$ at the $95 \%$ confidence level [50], indicated that there is no significant difference in the resultant concentrations. The $\mathrm{R}$ software was also used to determine the linear adjusted regression coefficients [50]. Certified standards obtained from IAEA and NIST, standards IAEA 085 and NIST 1515.

It is of essence to describe variability among observed variables, that is, the concentrations of the elements in the hair, that could be correlated in terms of a potentially lower number of unobserved variables [51]. This variability can be determined by factor analysis
(FA) or principal component analysis (PCA) [51, 52]. In factor analysis an assumption that an underlying causal model exists, was made. Although many hair analyses have been performed, there still exists an inadequate understanding of the hair system and the elemental distribution in the hair. PCA is therefore more applicable since it simply entails the reduction of variables, without the need of any knowledge of correlations that might exist. For completion, both factor analysis and PCA were performed.

Normal values (Norms) for the elements were obtained from [32-36, 53]. The minimum detection limits (MDLs) were obtained from the X-ray emission analysis. 
Table 5. Average concentrations and the standard deviations, in ppm, of the promotive and toxic elements in the hair specimens. ND indicates that the concentration of the element is below the minimum detection limits (MDLs, also shown) as performed with X-ray emission. Concentrations less than $10 \mathrm{ppm}$ is expressed to the first decimal, and those of $10 \mathrm{ppm}$ or higher concentration to whole numbers.

\begin{tabular}{|c|c|c|c|c|c|c|c|c|}
\hline Place & Gender & $\mathrm{Br}$ & $\mathrm{V}$ & $\mathrm{Ti}$ & $\mathrm{Ni}$ & $\mathrm{Sc}$ & $\mathrm{Pb}$ & As \\
\hline Bahri & Female & ND & $1.8 \pm 0.3$ & ND & $14 \pm 3$ & $39 \pm 9$ & ND & $6.0 \pm 0.2$ \\
\hline Khartoum & Female & ND & $2.6 \pm 0.1$ & $16 \pm 3$ & $35 \pm 7$ & $16 \pm 1$ & ND & $2.1 \pm 0.3$ \\
\hline Omdurman & Female & ND & $4.2 \pm 0.1$ & $1.6 \pm 0.4$ & $3.5 \pm 0.3$ & $3.6 \pm 0.1$ & $0.2 \pm 0.1$ & ND \\
\hline Bahri & Male & ND & ND & $16 \pm 4$ & $9.0 \pm 0.2$ & $3.5 \pm 0.1$ & $12 \pm 3$ & $6.0 \pm 0.2$ \\
\hline Khartoum & Male & ND & ND & ND & $50 \pm 13$ & $47 \pm 6$ & $13 \pm 2$ & $2.1 \pm 0.5$ \\
\hline Omdurman & Male & $4.0 \pm 0.1$ & $0.7 \pm 0.4$ & ND & $35 \pm 7$ & $26 \pm 2$ & $32 \pm 4$ & $10 \pm 2$ \\
\hline Gedaref & Female & $1.9 \pm 0.4$ & ND & ND & $7.0 \pm 0.1$ & $33 \pm 6$ & $12 \pm 2$ & ND \\
\hline Halfa & Female & ND & $11 \pm 2$ & $1.9 \pm 0.7$ & $0.9 \pm 0.2$ & $19 \pm 4$ & ND & ND \\
\hline Kassala & Female & ND & $7.0 \pm 0.1$ & ND & $5.0 \pm 0.9$ & $9.0 \pm 0.1$ & $12 \pm 3$ & ND \\
\hline Gedaref & Male & ND & ND & $3.3 \pm 0.2$ & $2.4 \pm 0.1$ & $4.7 \pm 0.1$ & ND & $2.5 \pm 0.4$ \\
\hline Halfa & Male & $6.7 \pm 0.2$ & ND & ND & $8.1 \pm 0.2$ & $10 \pm 2$ & $12 \pm 1$ & $0.7 \pm 0.4$ \\
\hline Kassala & Male & ND & ND & $2.2 \pm 0.1$ & $3.7 \pm 0.1$ & $4.7 \pm 0.1$ & ND & $2.5 \pm 0.5$ \\
\hline Atbara & Female & ND & $27 \pm 5$ & $1.8 \pm 0.1$ & $58 \pm 13$ & $68 \pm 8$ & $43 \pm 6$ & ND \\
\hline Dongala & Female & ND & $9.7 \pm 0.3$ & ND & $29 \pm 2$ & $72 \pm 9$ & $36 \pm 2$ & $0.8 \pm 0.2$ \\
\hline Marawe & Female & ND & $6.2 \pm 0.5$ & $0.9 \pm 0.2$ & $18 \pm 1$ & $89 \pm 14$ & ND & $0.8 \pm 0.6$ \\
\hline Atbara & Male & $6.4 \pm 0.1$ & $15 \pm 2$ & $19 \pm 4$ & $140 \pm 17$ & $140 \pm 8$ & $12 \pm 2$ & $2.5 \pm 0.1$ \\
\hline Dongala & Male & ND & $17 \pm 4$ & ND & $88 \pm 11$ & $35 \pm 3$ & $15 \pm 3$ & ND \\
\hline Marawe & Male & ND & $22 \pm 6$ & ND & $49 \pm 13$ & $7.0 \pm 0.1$ & $7.8 \pm 0.2$ & $0.8 \pm 0.3$ \\
\hline Al Fashir & Female & ND & ND & ND & ND & $34 \pm 5$ & ND & ND \\
\hline Al Obied & Female & $1.5 \pm 0.4$ & $4.8 \pm 0.1$ & ND & ND & $36 \pm 4$ & ND & ND \\
\hline Nyala & Female & ND & ND & ND & $12 \pm 2$ & $21 \pm 5$ & ND & ND \\
\hline Al Fashir & Male & ND & ND & $12 \pm 1$ & $3.9 \pm 0.1$ & $37 \pm 2$ & ND & $1.2 \pm 0.2$ \\
\hline Al Obied & Male & ND & ND & ND & $5.8 \pm 0.1$ & $28 \pm 6$ & ND & $1.5 \pm 0.2$ \\
\hline \multirow[t]{3}{*}{ Nyala } & Male & $3.3 \pm 0.1$ & ND & ND & $3.0 \pm 0.1$ & $12 \pm 3$ & $11 \pm 2$ & $9.2 \pm 0.3$ \\
\hline & Norms & $\leq 10$ & $0.5-2.8$ & $\leq 4.5$ & $2.0-5.3$ & $0.5-2.9$ & $\leq 4$ & $\leq 0.9$ \\
\hline & MDL's & 0.7 & 0.5 & 2.5 & 1.5 & 2.4 & 3.9 & 0.2 \\
\hline
\end{tabular}

\section{Results and Discussions}

The concentrations and standard deviations of the quantity elements, $\mathrm{P}, \mathrm{S}, \mathrm{Cl}, \mathrm{K}$ and $\mathrm{Ca}$ in the hair specimens are shown in Table 3. Phosphorus (P) was only found the hair of men residing in the eastern $(1190 \pm 633) \mathrm{ppm}$ and northern $(940 \pm 892)$ ppm regions. More so, only $\mathrm{n}=7(3.8 \%)$ of the students had hair $\mathrm{P}$ concentrations that were within the normal values and $\mathrm{n}=84(45.9 \%)$ had concentrations less than the MDL of $1.6 \mathrm{ppm}$. These high average values indicate that the students originating from the eastern and northern regions were in contact with a $\mathrm{P}$ contaminating environment for long periods of time. It is also tentative to compare the inter-gender and inter-location data since the standard deviations is at times approximately $50 \%$.

The $\mathrm{S}$ concentrations of the Eastern and Northern regions are within the normal concentration levels. Those of the central and western regions are lower than the normal concentration values. Since the concentrations are not in excess, it can be concluded at this stage that these values are physiological (or ethical) in nature, and no $\mathrm{S}$ contamination occurred. Of the $\mathrm{Cl}$ concentrations values $92 \%$ were determinable. The average and standard deviation values were however $456 \pm 567,735 \pm 667,975 \pm 542$ and $524 \pm 368$ in ppm for the respective regions central, eastern, northern and western. These standard deviations in concentrations 


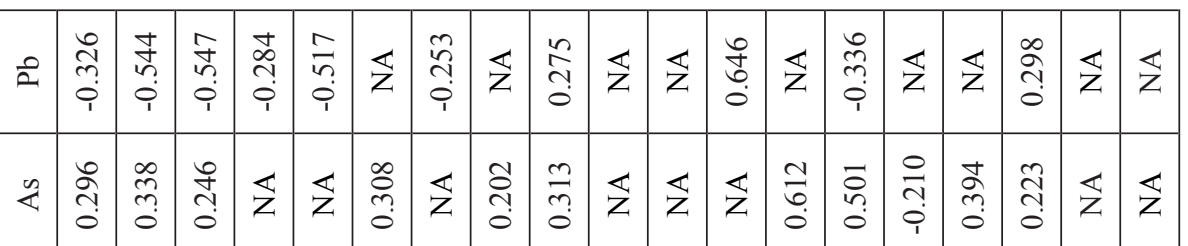

品

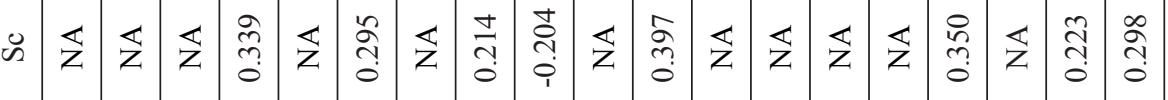

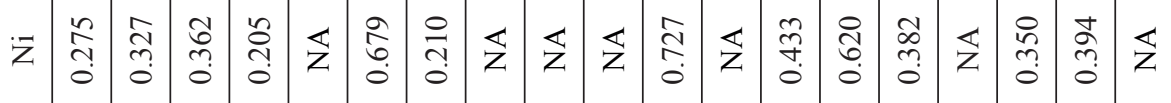

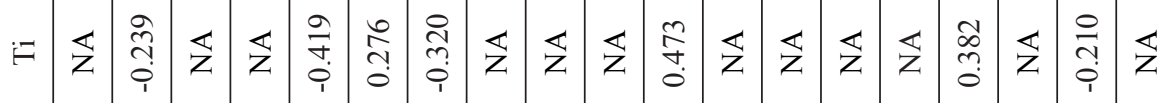

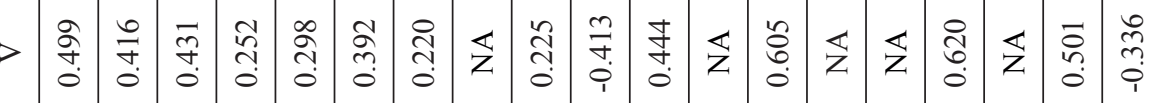

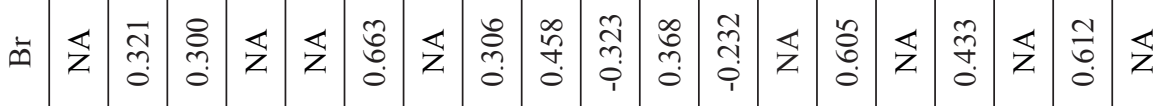

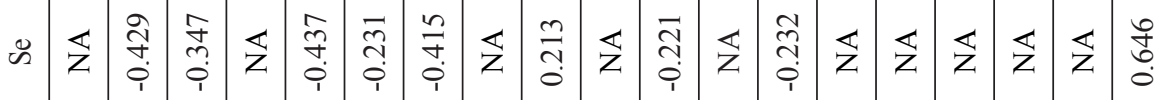

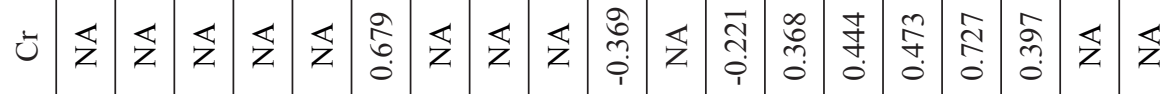

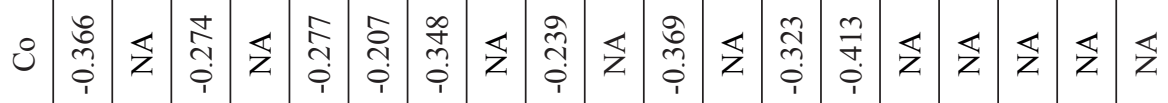

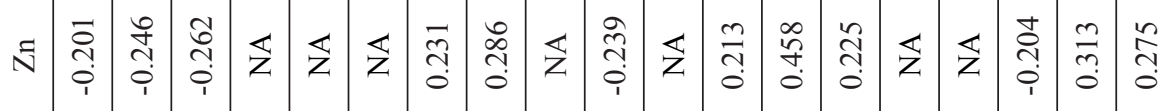

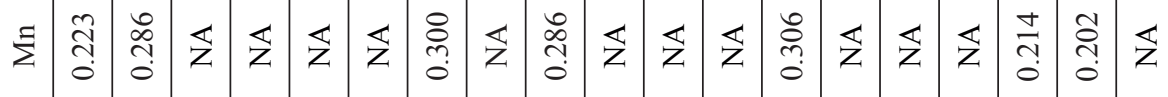

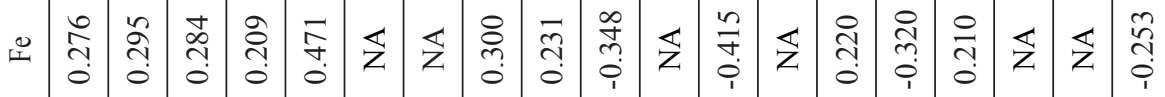

:

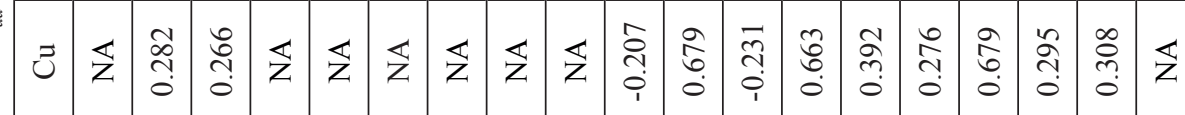

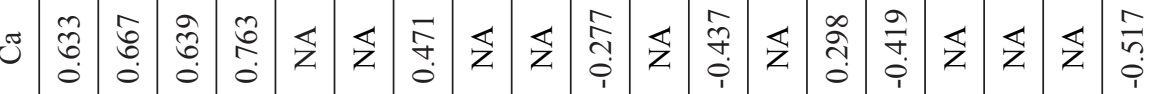

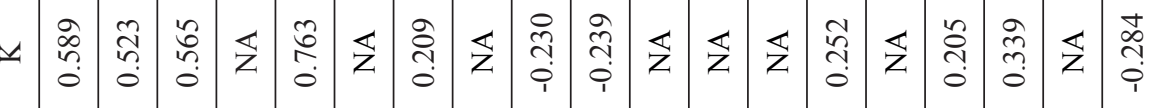

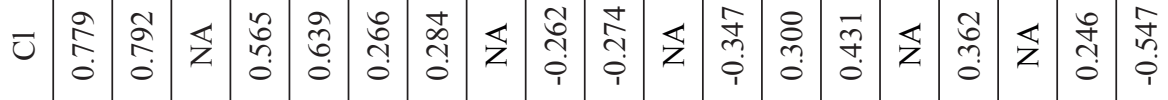

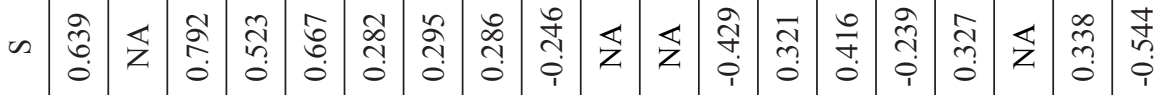

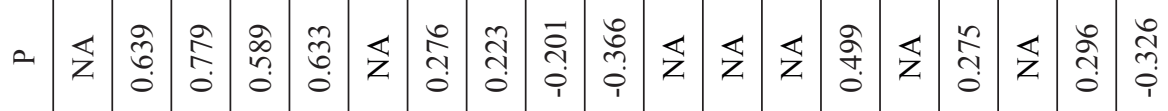

a ⿰冫 
Table 7. Correlation of the principal components, $p c a$, and the elements for limitation (of $10 \%$ dependence) $-0.100 \geq p c a \geq 0.100$. NA indicates that the dependency is not within the limitation.

\begin{tabular}{|c|c|c|c|c|c|c|}
\hline Elem & PCA 1 & PCA 2 & PCA 3 & PCA 4 & PCA 5 & PCA 6 \\
\hline $\mathrm{P}$ & 0.310 & 0.174 & NA & 0.222 & NA & 0.307 \\
\hline S & 0.344 & 0.142 & NA & NA & 0.324 & -0.149 \\
\hline $\mathrm{Cl}$ & 0.356 & 0.141 & NA & NA & 0.180 & NA \\
\hline K & 0.248 & 0.227 & 0.211 & 0.291 & -0.194 & 0.141 \\
\hline $\mathrm{Ca}$ & 0.300 & 0.316 & NA & NA & -0.161 & NA \\
\hline $\mathrm{Cu}$ & 0.211 & NA & -0.188 & NA & -0.434 & -0.348 \\
\hline $\mathrm{Fe}$ & 0.108 & NA & -0.219 & 0.379 & NA & -0.392 \\
\hline $\mathrm{Mn}$ & -0.183 & NA & 0.118 & 0.127 & 0.535 & -0.342 \\
\hline $\mathrm{Zn}$ & NA & -0.213 & -0.502 & NA & -0.270 & NA \\
\hline $\mathrm{Co}$ & 0.188 & -0.342 & 0.310 & -0.125 & -0.226 & NA \\
\hline $\mathrm{Cr}$ & 0.221 & -0.326 & -0.313 & -0.144 & 0.121 & NA \\
\hline $\mathrm{Se}$ & -0.213 & -0.117 & NA & 0.435 & NA & 0.351 \\
\hline $\mathrm{Br}$ & NA & -0.140 & 0.325 & 0.431 & -0.173 & -0.299 \\
\hline $\mathrm{V}$ & NA & -0.271 & 0.400 & NA & NA & 0.137 \\
\hline $\mathrm{Ti}$ & 0.245 & -0.338 & 0.207 & NA & NA & NA \\
\hline $\mathrm{Ni}$ & 0.302 & -0.188 & -0.122 & NA & NA & 0.373 \\
\hline $\mathrm{Sc}$ & 0.205 & -0.376 & 0.113 & -0.139 & NA & -0.275 \\
\hline As & -0.243 & -0.212 & NA & 0.423 & -0.110 & NA \\
\hline $\mathrm{Pb}$ & 0.165 & -0.240 & -0.267 & 0.256 & 0.352 & NA \\
\hline
\end{tabular}

Table 8. Factor analysis in terms of the loadings $(l)$ and communalities (Comm), $c$, after varimax rotation. The communality was limited to $c \geq 1000$.

\begin{tabular}{|c|c|c|c|c|c|c|c|}
\hline El & FA 1 & FA 2 & FA 3 & FA 4 & FA 5 & FA 6 & Comm \\
\hline P & 386 & 191 & -605 & 62 & 7 & -51 & 557662 \\
\hline S & 0 & 0 & 0 & 0 & 0 & 0 & 0 \\
\hline Cl & 642 & 130 & -222 & 8 & 133 & -90 & 504382 \\
\hline K & 302 & 759 & -168 & 95 & 41 & -12 & 706337 \\
\hline $\mathrm{Ca}$ & 179 & 167 & -71 & 206 & -25 & 15 & 108318 \\
\hline $\mathrm{Zn}$ & -30 & -11 & 5 & 17 & 2 & -70 & 6240 \\
\hline $\mathrm{Co}$ & -2 & 7 & -1 & 4 & 50 & 4 & 2582 \\
\hline$\sigma$ & 678593 & 665951 & 443212 & 54835 & 18052 & 14878 & 1885521 \\
\hline$\% \sigma$ & 0 & 0 & 0.237 & 0 & 0 & 0 & 1 \\
\hline
\end{tabular}

are relatively high and it is inferred at this stage that $\mathrm{Cl}$ contamination occurred in all four regions.

All the $\mathrm{K}$ concentrations are in excess of the normal values. A similar trend as with $\mathrm{S}$ and $\mathrm{Cl}$ is present in the $\mathrm{K}$ concentrations, that is, the concentration values for the central and western regions are lower than those of the eastern and northern regions.
The concentrations of $\mathrm{Ca}$ in the central $(364 \pm 181)$ ppm and western regions $(630 \pm 149)$ ppm are within the normal concentration range. As with the other element concentrations, the $\mathrm{Ca}$ concentrations of the eastern and northern regions were in excess of the normal values. $\mathrm{Ca}$ contamination might therefore have occurred in these regions. 

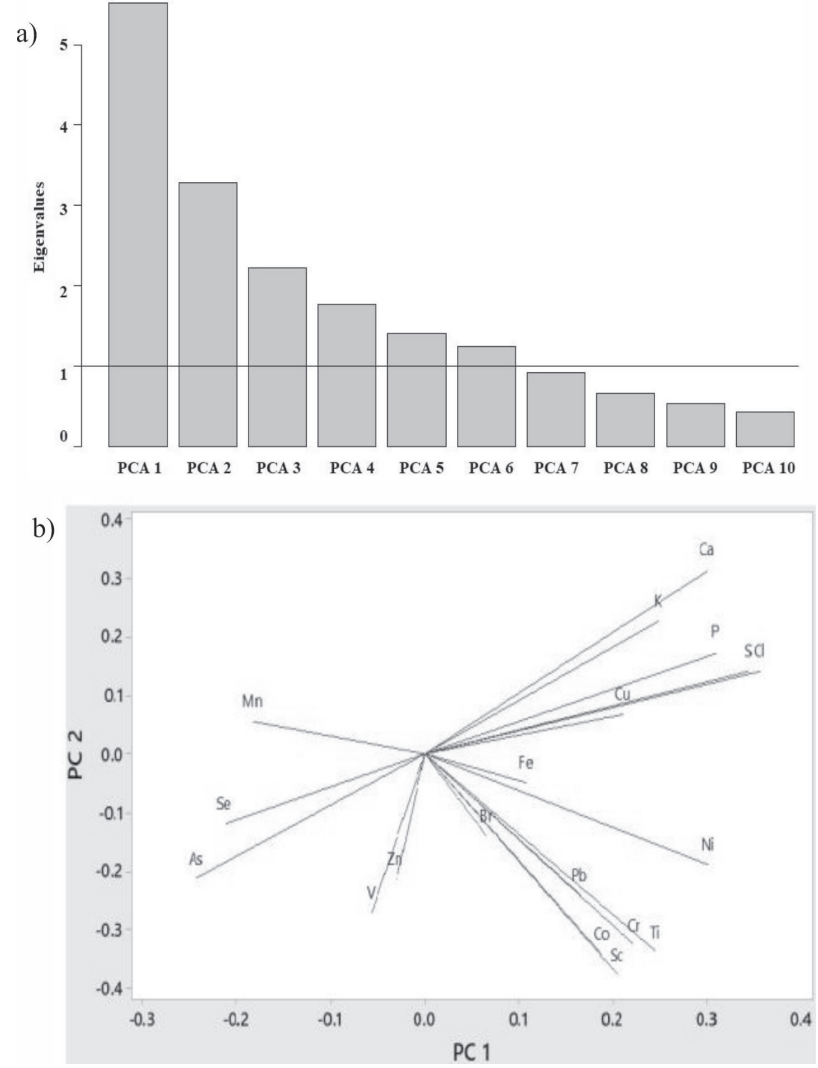

Fig. 2. Principal component analysis of the elemental concentrations: a) bar scree plot of the eigenvalues (variances), b) Plot of the eigen-values (variances) on PC1 and PC2.

Of the quantity elements, S was not in excess and the lower than normal concentrations are due to ethnic origins. The high $\mathrm{P}, \mathrm{Cl}, \mathrm{K}$ and $\mathrm{Ca}$ concentrations could only be due to contamination by compounds of $\mathrm{PO}_{4}{ }^{3-}, \mathrm{HPO}_{4}{ }^{2-}, \mathrm{H}_{2} \mathrm{PO}_{4}^{-}, \mathrm{Ca}^{2+}, \mathrm{K}^{+}, \mathrm{Cl}^{-}$, organic $\mathrm{P}$ and $\mathrm{POCl}_{\mathrm{x}}$.

The average concentrations and standard deviations of essential elements in the hair specimens, are shown in Table 4. Of the $\mathrm{Cu}$ concentrations, $84 \%$ was within the normal concentration range. Hair of students from the eastern and northern regions contained more $\mathrm{Cu}$ than those of the central and western regions, though these concentrations were within the normal values. Even though the average concentration for the eastern region $(10.9 \pm 4.5) \mathrm{ppm}$ is marginally greater than that of western region $(10.4 \pm 4.8) \mathrm{ppm}$, the trend is similar to the trend of the quantity elements.

Similarly, $85 \%$ of the hair specimens contained $\mathrm{Fe}$ concentrations was within the normal values. Only hair from male students of the Bahri area had an $\mathrm{Fe}$ content of less than $0.2 \mathrm{ppm}$. In addition, hair of students from the eastern and northern regions contained more Fe than those of the central and western region, although these concentrations were within the normal values.

Mn was only found in $\mathrm{n}=121(66.1 \%)$ of the students; and was not found in hair of most eastern and northern regions students $(\mathrm{n}=62)$. Hence, concentrations of $\mathrm{Mn}$ in the hair of these students cannot be used in correlation. The concentrations of $\mathrm{Zn}, \mathrm{Co}$ and $\mathrm{Cr}$ were relatively high; more than an order of magnitude in some instances. These high concentrations are of great concern as underlying metallic-caused diseases might be present. Se was only present in normal concentration ranges in hair of students from the western region. $\mathrm{Br}$ was only present in $n=34(19.6 \%)$ of the hair samples of the students.

Similarly, the concentrations of $\mathrm{V}, \mathrm{Ni}, \mathrm{As}$ and $\mathrm{Pb}$, given in Table 5, were also found in low percentages of the hair samples. Ti concentrations were relatively high. Of grave concern is the relatively high concentrations of $\mathrm{As}$ and $\mathrm{Pb}$ in the hair samples.

The linear adjusted regression coefficients, $-0.200 \geq r_{a d} \geq 0.200$, inter-element correlation are given in Table 6 . Concentration of $\mathrm{P}$ correlated positively with $\mathrm{Cl}$ (0.779), S (0.639), K (0.589), Ca (0.633) and $\mathrm{Ni}(0.499)$. There was high inter-element correlation (0.659) among the quantity elements $\mathrm{P}, \mathrm{S}, \mathrm{Cl}, \mathrm{K}$ and $\mathrm{Ca}$. Importantly, the high correlations of toxic elements $\mathrm{As}$ and $\mathrm{Pb}$. As correlates positively with $\mathrm{Se}$ (0.646). However, the element concentration correlated negatively with those of $\mathrm{S}(-0.544), \mathrm{Cl}$ $(-0.547)$ and $\mathrm{Ca}(-0.517)$. Hence $\mathrm{As}$ is present with Se. The Co concentration was the most negatively correlated, which is evident from the abnormally high concentration values, whereas $\mathrm{Mn}$ was only positively correlated.

Interest was also focused on determining levels of variability in elemental concentrations of the elements such as $\mathrm{P}, \mathrm{S}, \mathrm{Cl}, \mathrm{K}$ and $\mathrm{Ca}$. In addition, the objective of this study to assess the concentration profiles of trace and toxic elements. The scree plot of the principle components (PCA) and the eigenvalues is shown in Fig. 2a). The eigenvalues were set to limit of unity. Consequently, six components were identified, which was indicative the wide variety of ores found in most of the regions. The dependence of the element concentrations on the first and second principal components is shown in Fig. 2b). The Mn concentration was in principle only negatively dependent on PCA 2. The quantity elements are equally dependent on PCA 1 and PCA 2. The promotive elements were positively correlated with PCA 1 and negatively correlated with PCA 2. K was the only element that was dependent on all six components. The $\mathrm{Zn}$ concentration correlated only negatively on the PCAs.

Factor analysis, in terms of the loadings (l) and communalities (c), is shown in Table 7. The $\mathrm{S}$ concentration, although $l=0$ and $c=0$, was included to illustrate the element concentration had no communality; confirming the inference that the deviations in $\mathrm{S}$ concentration could be ascribed to ethnical differences. All the concentrations of the other quantity elements exhibited high communalities. Of the remaining elements only $\mathrm{Zn}$ and Co concentrations showed commonalities of more than 1000 . 


\section{Conclusions}

Although the students have been residing for a long period in the urban area of the capital city, they spent working holidays the rural regions. As there is little mining and agricultural activities per se in the urban areas, these students have thus been polluted during their holiday periods. The high concentrations of the toxic elements are of great concern. More so, even though the students after visual inspection appeared normal, such high toxic concentrations would have a detrimental effect on the organs in the body. Should such detrimental effects be found, then forensic investigations should be followed. It is recommended that further clinical evaluations should be performed to assess direct and indirect organ malfunctions.

\section{Acknowledgements}

The authors would like to thank TWAS-UNESCO and the Department of Materials Research at iThemba LABS, Faure, Rep. of South Africa for their support. The authors are also grateful to Prof. Dr. R. Henkel of the University of the Western Cape, Bellville, RSA, for allowing this study, Dr. Z. Mohammed, Mr. ME Yaseen and Dr. J. Saad of the Northern Border University for their assistance in the statistical and computer analysis of the results. The authors express their sincere gratitude to the Research Section of the Northern Border University of the Kingdom of Saudi Arabia for the generous funding of this research project (SCI-20161-6-F-5816).

\section{Conflict of Interest}

The authors declare no conflict of interest.

\section{References}

1. HORN J., ROSENBAND L.N., SMITH M.R. Reconceptualizing the industrial revol-ution, MIT Press, USA, 2010.

2. SALEM, T., AHMED, S.S., HAMED, M., ABD ELAZIZ, G.H. Risk assessment of hazardous impacts on urbanization and industrialization activities based upon toxic substances. Glob. J. Environ. Sci. Manage. 2 (2), 163, 2016.

3. LU S.Y., ZHANG H.M., SOJINU S.O., LIU G.H., ZHANG J.Q., NI H.G. Trace elements contamination and human health risk assessment in drinking water from Shenzhen, China, Environ. Monit. Assess. 187 (1), 4220, 2015.

4. YANG C.Y, WU M.L, CHOU Y.Y, LI SY., DENG J.F., YANG W.C., NG Y.Y. Essential trace element status and clinical outcomes in long-term dialysis patients: A twoyear prospective observational cohort study, Clin. Nutr. 31 (5), 630, 2012
5. NOUIOUI M.A., ARAOUD M., MILLIAND M.L., BESSUEILLE-BARBIER F., AMIRA D., AYOUNIDEROUICHE L., HEDHILI A., Evaluation of the status and the relationship between essential and toxic elements in the hair of occupationally exposed workers. Environ. Monit. Assess., 190 (12), 731, 2018.

6. STENEHJEM A.E., VAHTER M., NERMELL B., AASEN J., LIERHAGEN S., MØRLAND J., JACOBSEN D. Slow recovery from severe inorganic arsenic poisoning despite treatment with DMSA (2.3-dimercaptosuccinic acid). Clin. Toxicol., 45 (4), 424, 2007.

7. EASTMAN R.R., JURSA T.P., BENEDETTI C., LUCCHINI R.G., SMITH D.R., Hair as a biomarker of environmental manganese exposure. Environ. Sci. Tech., 47 (3), 1629, 2013.

8. LUCCHINI R.G., GUAZZETTI, S., ZONI S., DONNA F., PETER S., ZACCO A., SALMISTRARO M., BONTEMPI E., ZIMMERMAN N.J., SMITH D.R., Tremor, olfactory and motor changes in Italian adolescents exposed to historical ferro-manganese emission. Neurotox., 33 (4), 687, 2012.

9. AGAH H., LEERMAKERS M., GAO Y., FATEMI S.M.R., KATAL M.M., BAEYENS W., ELSKENS M., Mercury accumulation in fish species from the Persian Gulf and in human hair from fishermen. Environ. Monit. Assess., 169 (1-4), 203, 2010.

10. AGAH H., LEERMAKERS M., ELSKENS M., FATEMI S.M.R., BAEYENS W. Total mercury and methylmercury concentrations in fish from the Persian Gulf and the Caspian Sea. Water, Air Soil Poll., 181, 95, 2007.

11. WEIHE P., GRANDJEAN P., JORGENSEN P.J., Application of hair mercury analysis to determine the impact of a seafood advisory. Environ. Res., 97, 201, 2005.

12. KORMAWA P., AFEIKHENA J. Renewing industrialization strategies in Africa, Beyond Midd Inc Africa: Transf. Afr. Econ. Sustained Growth with Rising Employ and Inc. ReSAKSS Annual Trend and Output Report, 2015.

13. SAMPATH P.G. Sustainable industrialization in Africa: Toward a new development, Springer-Verlag, 2016.

14. ELSAMANI Y. Minerals potential and resources in Sudan, in: $17^{\text {th }}$ Africa OILGASMINE, Khartoum, Vol. 1 of Africa OILGASMINE, 2015.

15. CHEVRILLON-GUIBERT R. The gold boom in Sudan. challenges and opportunities for national players, Inter. Develop. Pol./Revue Internationale de politique de d'eveloppement 7 (1) 2016 [In French].

16. ABDELBAGI A.M., MUSTAFA M.A.G., ELDEEN A.E.S. Concentrations of trace elements in human hair as a biomarker expose to environmental contamination. Int. J. Sci. Res. Innov. Tech., 4 (2), 38, 2017.

17. TAKAGI Y., MATSUDA S., IMAI S., OHMORI Y., MASUDA T., VINSON J.A., MEHRA M.C., PURI B.K., KANIEWSKI A., Trace elements in human hair: an international comparison. Bull. Environ. Contam. Toxicol. 36 (6), 1986.

18. ELSAMANI Z.A.E. Environmental study of Khartoum refinery liquid effluents, Ph.D. thesis, Sudan University of Science and Technology, Khartoum, Sudan, 2016.

19. EBAIDALLA E.M., Causality between government expenditure and national income: Evidence from Sudan. J. Econ. Coop. Develop., 34 (4), 61, 2013.

20. AL T.A. Effects of acid-sulfate weathering and cyanide containing gold tailings on the transport and fate of mercury and other metals in Gossan Creek: Murray Brook 
mine, New Brunswick, Canada. Appl. Geochem. 21 (11), 1969, 2006.

21. ZHANGXIONG H., DEJUN W., HAIXIA T., WENXIANG H., ZIQUAN W., QIANG L. Pollution Assessment of Heavy Metals in Soils and Plants around a Molybdenum Mine in Central China, Pol. J. Environ. Stud. 28 (1), 123, 2019

22. SUN L., FENG S. Heavy Metals in the Surface Soil around a Coalmine. Pollution Assessment and Source Identification, Pol. J. Environ. Stud. 28 (4), 2717, 2019.

23. NANGLIYA V ., SHARMA A., YADAV D., SUNDER S., NIJHAWAN S., MISHRA S. Study of trace elements in liver cirrhosis patients and their role in prognosis of disease, Biol. Trace Elem. Res. 165 (1), 35, 2015.

24. FAIRWEATHER-TAIT S.J., CASHMAN K. Minerals and trace elements, In Nutrition for the Primary Care Provider. Karger Publishers: Basel, Switzerland, 111, 42, 2015.

25. VERSIECK J. Trace elements in human body fluids and tissues, CRC Crit. Rev. Clin. Lab. Sci. 22 (2), 97, 1985.

26. FRIEDEN E. New perspectives on the essential trace elements, J. Chem. Edu. 6 (11), 915. 1985.

27. KOÇ E.R., ILHAN A., ZÜBEYDE AYTÜRK., ACAR B., GÜRLER M, ALTUNTAȘ A., KARAPIRLI M., BODUR A.S. A comparison of hair and serum trace elements in patients with Alzheimer disease and healthy participants, Turk. J. Med. Sci., 45 (5), 1034, 2015.

28. POPUGAEVA E., PCHITSKAYA E., BEZPROZVANNY I. Dysregulation of neuronal calcium homeostasis in Alzheimer's disease-a therapeutic opportunity? Biochem. Biophys. Res. Comm. 483 (4), 998, 2017.

29. PINEDA-VARGAS C., MARS J.A., GIHWALA D. Elemental concentration distribution in human fingernails: A 3D study, Nucl. Ins. Meth. Phys. Res. B., 238, 5, 2011.

30. MALEPFANE N. Elemental composition and fertiliser value of different types of human hair in South Africa. Thesis (M.Sc): University of KwaZulu-Natal, Durban, Rep. of South Africa, 2016.

31. ERDOĜAN B. Anatomy and Physiology of Hair, In Hair and Scalp Disorders. Rijeka Intech Open. 2017.

32. ROBBINS C.R. Chemical composition of different hair types, In Chemical and physical behavior of human hair, Springer: New York, USA, 105, 2012.

33. PRIYA M.D.L., GEETHA A. Level of trace elements (copper, zinc, magnesium and selenium) and toxic elements (lead and mercury) in the hair and nail of children with autism, Biol. Trace Elem. Res. 142 (2), 148, 2011.

34. BUFFOLI B., RINALDI F., LABANCA M., SORBELLINI E., TRINK A., GUANZIR OLI E., REZZANI R., RODELLA L.F. The human hair: From Anatomy to Physiology, Int. J. Derm. 53, 331, 2013.

35. KOSANOVIC M., JOKANOVIC M. Quantitative analysis of toxic and essential elements in human hair clinical validity of results, Environ. Monit. Assess. 174 (1-4), 635, 2011.

36. MIKULEWICZ M., CHOJNACKA K., GEDRANGE T., GÓRECKI H. Reference values of elements in human hair: A systematic review, Environ. Toxicol. Pharmacol. 36 (3), 1077, 2013.

37. PRAGSTA F., STIEGLITZB K., RUNGEC H., RUNOWD K.D, QUIGE D., OSBORNEF R., CHRISTIAN RUNGEC C., ARIKIG J. High concentrations of lead and barium in hair of the rural population caused by water pollution in the Thar Jath oilfields in South Sudan, Foren. Sci. Int. 274, 99, 2017.

38. SKALNY A.V., SKALNAYA M.G., TINKOV A.A., SEREBRYANSKY E.P., DEMIDOV V.A., LOBANOVA Y.N., GRABEKLIS A.R., BEREZKINA E.S., GRYAZEVA I.V., SKALNY A.A., SKALNAYA O.A., ZHIVAEV N.G., NIKONOROV A.A. Hair concentration of essential trace elements in adult non-exposed Russian population, Environ. Monit. Assess. 187 (11), 677, 2015.

39. TAMBURO E., VARRICA D., AND DONGARRÀ G. Coverage intervals for trace elements in human scalp hair are site specific, Environ. Toxicol. Pharmacol. 39 (1), 70, 2015.

40. LI Q., CHEN L., YANG Z., YE Z., HUANG Y., HE M., ZHANG S., FENG X., GONG W., ZHANG Z., ZHAO W., LIU C., QU S., HU R. Metabolic effects of bariatric surgery in type 2 diabetic patients with body mass index $<35 \mathrm{~kg} / \mathrm{m}^{2}$ ", Diabetes Obes. Metab. 14 (3), 262, 2012.

41. JOHANSSON S.A., CAMPBELL J.L., MALMQVIST K.G. Particle-induced X-ray emission spectrometry (PIXE), John Wiley \& Sons: New Jersey, USA, 1995.

42. MARS J.A. Applications of the Nuclear Microprobe in Materials Science, Doctorate of Technology Thesis (D.Tech): Cape Peninsula University of Technology, Bellville, Rep. of South Africa, 2004.

43. MARS J.A., KUNSEVI-KILOLA C., GIHWALA D. PIXE and RBS analysis of serum specimens of rats fed with tea extracts to ascertain elemental absorption, J. Radioanal. Nucl. Chem, 309 (1), 405, 2016.

44. FELDMAN L.C., MAYER J.W. Fundamentals of surface and thin film analysis, North Holland, Elsevier Science Publishers: Amsterdam, The Netherlands, 1986.

45. PROZESKY V.M., PINEDA C.A., MESJASZPRZYBYLOWICZ J., PRZYBYLOWICZ W.J., CHURMS C.L., SPRINGHORN K.A., MORETTO PH., MICHELET C., CHIKTE U., WENZL P. The biological research programme of the nuclear microprobe at the National Accelerator Centre, Faure, Nucl. Ins. Meth. Phys. Res, B. 161, 852, 2000.

46. IYENGAR G.V., KOLLMER W.E., BOWEN H.J.M. The elemental composition of human tissues and body fluids: A compilation of values for adults. VCH Publishers, 1988.

47. RYAN C.G. PIXE and the nuclear microprobe: Tools for quantitative imaging of complex natural materials, Nucl. Ins. Meth. Phys. Res. B. 269 (20), 2151, 2011.

48. MAYER M. Improved physics in SIMNRA 7, Nucl. Ins. Meth. Phys. Res, Sect B. 332, 176, 2014.

49. IHAKA R., GENTLEMAN R. R: A language for data analysis and graphics, J. Comput. Graphic Stat, 5 (3), 299, 1996.

50. RONALD L. W., NICOLE A. L. The ASA's statement on p-values: context, process, and purpose, Am. Stat. 70 (2), 129, 2016

51. KLINE P. An easy guide to factor analysis, Routledge: Abingdon-on-Thames, UK, 2014.

52. AYYUB B.M., MCCUEN R.H. Probability, statistics, and reliability for engineers and scientists. CRC press: New York, USA, 2006.

53. SENOFONTE O., VIOLANTE N., CAROLI S. Assessment of reference values for elements in human hair of urban schoolboys, J. Trace Elem. Med. Biol. 14 (1), 6, 2000. 